\title{
„ВОГНЕННЕ ОКО” СПОКУСИ В ОДНОЙМЕННОМУ РОМАНІ ОЛЕСЯ УЛЬЯНЕНКА
}

\author{
ФЕЛІКС ШТЕЙНБУК
}

Університет ім. Яна Коменського у Братиславі, Братислава - Словаччина feliks.shteinbuk@uniba.sk; ORCID: https://orcid.org/0000-0002-4852-815X

\section{„OGNISTE OKO” POKUSY \\ W POWIEŚCI O TYM SAMYM TYTULE OŁESIA ULIANENKI}

FELIKS SZTEINBUK

Uniwersytet im. Jana Komeńskiego w Bratysławie, Bratysława - Słowacja

\begin{abstract}
STRESZCZENIE. Artykuł poświęcony jest rozważaniom o powieści Ołesia Ulianenki Ogniste oko na podstawie cielesno-mimetycznej metody analizy dzieł sztuki. Dzięki zastosowaniu tej najnowszej metodologii wyciągnięto wniosek zaprzeczający tradycyjnym krytycznym refleksjom na temat twórczości pisarza i wedlug którego powieść opiera się nie na apokaliptycznych wizjach, ale na koncepcie pokusy. Natomiast znaczenie pokusy jest określane przez korelację między pragnieniem władzy, kobietą, seksem a śmiercią, symbolicznym echem której jest obraz nieba z wielkim okiem pośrodku - z okiem płonącym ogniem pokusy, czyli życiodajnym ciepłem i światłem. Jednak droga do nich wiedzie, według Ołesia Ulianenki, co najmniej przez karnawałową przemianę okrucieństwa w miłosierdzie, zgrozy w zachwyt, żądzy w czułość, wstrętu w rozkosz i odwrotnie.
\end{abstract}

Słowa kluczowe: Ołeś Ulianenko, pokusa, władza, kobieta, seks, śmierć

\section{"THE FIERY EYE" OF SEDUCTION IN OLES ULYANENKO'S NOVEL OF THE SAME NAME}

\author{
FELIKS SHTEINBUK
}

Comenius University in Bratislava, Bratislava - Slovensko 
ABSTRACT. The article is an interpretation of Oles Ulyanenko's novel Fiery Eye on the principles of corporal-mimetic method for analyzing fiction. Having applied this innovative methodology, the conclusion is reached that the novel is not based on an apocalyptic vision but on a seduction phenomenon. This conclusion disputes traditional critical reflections on Oles Ulyanenko's literary works. The content of seduction is determined by the correlation between the desire for power, woman, sex and death. They are symbolically echoed by the image of a sky with an enormous eye in the center, blazing with seductive fire. This fire is vivifying warmth and light. According to Oles Ulyanenko, the way there runs through a carnival turning cruelty into mercy, horror into delight, hatred into tenderness, disgust into pleasure, and vice versa.

Keywords: Oles Ulyanenko, seduction, power, woman, sex, death

1

7 серпня 2020 року минуло вже десятиріччя з дня смерті найбільш контроверсійного та складного сучасного українського письменника Олеся Ульяненка. Втім, і за життя митця, а тим більше після його смерті надзвичайно гострою була і залишається проблема, пов' язана з адекватною фаховою рецепцією його творчості. Внаслідок цього більшість нечисленних дослідників його спадщини зазвичай вдаються не стільки до професійної критики, скільки до ригористичних оскаржень у дусі якогось релігійного трибуналу чи принаймні пріснопам'ятної Національної експертної комісії $з$ питань захисту суспільної моралі, що вперше, але, на щастя, востаннє в історії незалежної України, 2009 року заборонила один із романів письменника.

Мету цієї статті вбачаємо в тому, аби запропонувати альтернативний до традиційного варіант теоретико-літературного аналізу, що грунтується на засадах розробленого та апробованого у тракті докторських і постдокторських студій тілесно-міметичного методу розгляду художніх творів. Його сутність проявляється в тому, що літературні тексти передусім досліджуються з огляду на їхню тілесну детермінованість, через що сам метод можна визначити як метод аналізу тілесно-буттєвого підгрунтя художнього дискурсу [див. про це докл.: Штейнбук 2007, 2009, 2013].

У зв’язку зі сказаним необхідно передусім згадати, як свого часу Н. 3боровська, вдаючись до вкрай похмурої екзегетики щодо роману письменника Вогненне око, не шкодувала нищівного апломбу і намагалася довести, що „власне майбутнього в Ульяненка немає” і що „своїм творам Ульяненко настирливо намагається дати вигляд страшного сновидіння $з$ пророкуванням смерті" [Зборовська 1999]. При цьому негативна детермінація дослідниці була настільки непохитною, що навіть цитуючи один з епіграфів до цього твору, в якому (в епіграфі) фактично пропонуються особисті роздуми автора і за яким він (автор), мовляв, не співець смерти; вона навіть не посестра [Ульяненко 2013: 4], шановна літературознавиця все одно стверджувала, що „О. Ульяненко так само - не співець життя, оскільки життя в нього - нікчемність, гріх, блуд, те, за що переслідуватиме Вогненне Око” [Зборовська 1999]. 
Отже, мені важко погодитись із наведеними раціями, оскільки, по-перше, зміст роману категорично і послідовно їх заперечує, бо „Вогненне Око” нікого не „переслідує”, не притягає до жодної відповідальності і не карає. Воно, як, зрештою, і належить, тільки безпристрасно спостерігає згори за тим, що відбувається між людьми, які тирлуються під ним у суцільній, за Н. Зборовською, юдолі скорботи. Натомість переслідують, а надто - карають на горло, зокрема, брати́ Роздайбіди, або мент Гільмедов і К , або полковник служби безпеки Кравченко і навіть ,Лящ, червонопикий [...] невдаха-поет, що спромігся полишити кілька вузів, зажити слави неприкаяного модерніста, невтомного шукача пригод, місцевого джигуна в гурті прищавих студенток” [Ульяненко 2013: 96] тощо.

По-друге, Олесю Ульяненку, як на мене, не йдеться і про „страшне сновидіння”, та ще й „з пророкуванням смерті”. Адже якщо, з одного боку, згадати про його тяжіння до неонатуралізму, a, з іншого боку, взяти до уваги авантюрний характер сюжетних перипетій роману Вогненне око - перипетій, сповнених мандрами, пригодами, втечами-погонями, захованими скарбами і невірогідними зустрічами, звісно, з летальними для деяких персонажів наслідками, а не ,з пророкуванням” їх, то тоді стане очевидним, що „сновидіння” аналізований твір може нагадувати чи не в останню чергу.

Натомість, по-третє, неможливо оминути і той очевидний факт, за яким у Вогненному оці безпосередній характер авторських рефлексій містить усобі неприхований іронічний штиб, як-ось тоді, коли „халепа, ота видовжена й затягнута миттєвість, називається життям" [Ульяненко 2013: 211]. Або, наприклад, тоді, коли автору йдеться і справді про безпросвітність життя, яку він, проте, ілюструє, згадуючи „кілька конституцій кількох бананових країн, де все пройняте сонячним очікуванням демократії і справедливості, а ще, що набагато вірогідніше, - швидкий, негайний, днями очікуваний Кінець Світу" [Ульяненко 2013: 211].

Останній дотеп заслуговує на більш прискіпливу увагу, тому що са́ме в непозбутній апокаліптичності чи навіть, за Н. Зборовською, у „некрофілічному, сатанинському пафосі Олеся Уляненка"1 [цит. за: Харчук 2008: 22] нечисленні дослідники творчості письменника вбачають ледь не одну з основних рис, що характеризують поетику та проблематику його творів, позаяк очевидні іронічні конотації у цьому разі до уваги просто не беруться. Утім, у контексті щойно наведеного пасажу про Кінеи̧ь Cвimy, а також згадуваної в романі „маленької апокаліпси" [Ульяненко 2013: 134], пов’язаної з брудною кнайпою неподалік від Майдану з невибагливою назвою „Чайник” та зі, сказати б, непроминущою бабою Ориською, що „розвалилася ропухою за столом для посуду” [Ульяненко 2013: 134], навряд чи можна серйозно ставитися не тільки до „малої”, а й до будь-якої іншої, так би мовити, есхатології від Олеся Ульяненка.

\footnotetext{
${ }^{1}$ у написанні прізвища збережено авторську орфографію.
} 
За окресленої перспективи жодної критики не витримують і чи не усі інші подібні „моторошні” інтерпретаційні версії, до переліку яких входять не лише згадувані вище філіппіки Н. Зборовської, а й міркування I. Бондаря-Терещенка „про метафізичного героя, який декларує, що людина [...] безкінечно самотня у цьому безумному, безумному, безумному світі” [цит. за: Пуніна 2016: 106], або роздуми Т. Гутнікової, яка, за словами О. Пуніної, переконує в тому, що цей роман $є$ чомусь „квінтесенцією абсурдності, безглуздості, хаотичності, аморальності життя, що призводить до деградації особистості" [Пуніна 2016: 106], або також і рефлексії самої О. Пуніної. Остання з названих авторка, керуючись обраною експресіоністичною парадигмою, стверджує, що „y художньому світі роману Вогненне око категорія «homo errans»², виражена збірним образом спустошеного людства, $[\ldots]$ маркується $[\ldots]$ надмотивом крику”, а власне „крик спрямований проти соціальних обставин і породжений апокаліптичним баченням світу" [Пуніна 2016: 106].

Звісно, якщо розглядати літературну творчість взагалі і художню спадщину Олеся Ульяненка зокрема з позиції морально-етичних або суспільно-моральних імперативів, то тоді, певно, і справді було б важко не погодитись із висновками, яких дійшла цитована вище авторка. Проте у романі Апокаліпсис стається, власне, майже на початку твору, причому відбувається він безпосередньо на очах Родика, одного з двох протагоністів роману, який незадовго до того втік з родинної оселі, а на відповідний момент „запросто волочився залізничними вокзалами, вигрітий теплом власної свободи, вигодовуючи й без того ситих од людської крові тарганів та вошей” [Ульяненко 2013: 47]. I ось коли Родик і ще „один чоловік на прізвисько Кайф” [Ульяненко 2013: 47] перебували на зоровій відстані від будівлі київського Головпоштамту, розташованого на тоді ще не такому славетному, як зараз, майдані столиці, у них на очах і

на очах розімлілого від задухи люду під сівким дощем білий фронтон головпошти хилитнувся вліво, відтак осів, знявши брунатний вихор пилюги, поховавши під собою до десятка роззяв, що їм спало на думку помилуватися монументальністю сталінського ренесансу [Ульяненко 2013: 47].

Неабияка важливість цього епізоду не викликає жодних сумнівів, бо, крім очевидних алюзій щодо символічного кінця попередньої криваво-імперської доби, описаній події передували домірні до апокаліптичних образи „Великого Міста”, яке переповнюють

потоки людей, що плекають свою трагедію на ці часи, на ті часи, прийдешність котрих неминуча, як джергава коса смерті, як глевкі хвилі вселенського потопу, завчасно очіку-

\footnotetext{
${ }^{2}$ Примітка. Homo errans (лат.) - людина, що заблукала.
} 
ваного, а віра в неминучість Пришестя зацитькується, бо веселість натовпу злегка віддає некроманією [Ульяненко 2013: 43].

Проте це нагромадження, за Н. Зборовською, „некрофілічних” і „сатанинських” „жахів”, просякнуто більш ніж виразними іронічними конотаціями. а тому хоч Апокаліпсис і обернувся руйнацією фронтону і смертю кількох „роззяв”, та це у жоден спосіб не завадило ані Родику із Кайфом спостерігати за трагедією та водночас за „двійко[м] випещених красунь” [Ульяненко 2013: 43], які всілися неподалік від них, ані цим дерихвісткам, що вразили Родика „стрункістю [...] тіла, чистотою сірих очей, цнотливістю опущених вій, соковитих куточків уст, теж цілком спокійно попива[ти] пивце, мацькаючи помадою кольору стиглої вишні горлечка пляшок імпортного баварського пива" [Ульяненко 2013: 47-48]. Прикметним у цьому контексті видається і той факт, що історія зі зруйнованим фронтоном - це не вигадка, а реальна подія, яка сталася 2 серпня 1989 р. о 16 годині 20 хвилин і наслідком якої була загибель 11 осіб: двох москвичів-молодят, одного жителя Нового Осколу, трьох iз Південно-Сахалінська і п'ятьох киян. а тому згадка в романі про десяток „роззяв”, яких поховала під собою частина недолугої архітектурної споруди, заслуговує не менш, ніж на макабрично-іронічну інтерпретацію.

Щобільше, й епілог роману, в якому події відбуваються „через добрий десяток років" [Ульяненко 2013: 309], попри похмурий або, краще сказати, антиутопічно-попелястий кшталт, тим не менше теж не позбавлений іронічного присмаку - i тому́, що наратор згадує так званих „олюднених обрів” [Ульяненко 2013: 311], образ яких чи не автоматично викликає алюзію орків Дж. Толкіна, i, щонайголовніше, тому́, що в цьому епілозі образ „Вогненного Ока" за постапокаліптичних чи бодай антиутопічних умов власне пародіюється „вилізлим, зеленкуватим, мов у потопельника, оком місяця” [Ульяненко 2013: 313]. а на додаток роман ще й завершується цілком оптимістичною думкою, за якою все одно „дорога кудись виведе без огляду на керманичів” [Ульяненко 2013: 313]. Отже, роман постає як украй суперечливий і такий, що, безумовно, потребує не поверхових спостережень, а більш глибокого занурення у зміст.

Звісно, дуже хотілося б висловити припущення, за яким роман Олеся Ульяненка присвячено благородній та високій меті в тому сенсі, що „Віталія зацікавила таємниця людської душі” [Ульяненко 2013: 99]. Але пристати на такий здогад означало б опинитися щонайменше у сумнівній ситуації остільки, оскільки наведеній детермінанті щодо інтересів одного з голових героїв твору передує насмішкуватий коментар про те, що автору „напрошується недолуга думочка про містично-метафоричний вибух свідомості обох" [Ульяненко 2013: 67], тобто не тільки Віталія, а й Шмулєвича, і звернений автором до себе самого вже й зовсім знущально-глумливий зойк стосовно того, що, 
мовляв, „ет, повертай, бо найбільша з усіх людських глупот - описування духовного чи душевного стану героя" [Ульяненко 2013: 67].

Зрештою, відповідну авторську поставу можна вважати цілком обгрунтованою з огляду на його квазіантропологічні або й виразно мізантропічні спостереження, за якими

\begin{abstract}
ax, ox, ax... ніжні білі плечі їхніх коханок - тьху, пряма кишка од голови до сраки... ще там щось... а щелепи перемелюють ситнючу жратву, жіночки обтирають своїм мужичкам п’яні соплі, смалець із підборіддя ляпотить із жовтих іклів на щелепи, на груди. Вони блюють від пережеру в багаття, харкають сивухою дружинам в обличчя, а ті тусають їх у пуза, товчуть писки; дітлахи ревуть, сцють у багаття, і батьки напівкумарні позасинали, вихлебтавши все, за винятком води з ближніх водозбірень. Очунявши, дроблять курячі кісточки на пісок кутніми, що ними перетреш крицеву дротину. Тіло потребує... а душа... Хто їі вигадав? [Ульяненко 2013: 49].
\end{abstract}

Герой О. Ульяненка Віталій сам змушений був пережити неабиякий криваво-моторошний досвід, бо став свідком фактично масового фізичного знищення Гільмедовим, Гіменеєм та Різуном розташованого на березі річки табору жеброти на чолі із Циганом, а також продажу в сексуальне рабство усіх більшою чи меншою мірою здорових дітей з цього табору. Але, окрім того, що це був один із тих епізодів, у яких відсутні і макабрично-іронічні, і навіть будь-які глузливі конотації, він не позбавлений все ж таки якоїсь хворобливо-збоченої спокусливості, якщо, звісно, розуміти спокусу, за Ж. Бодріяром, як корелят „долі” або того, „що залишилося від долі, від азарту, від чаклунства, від задумів і нестями”, як „залишок мовчазної дієвості у заїждженому світі видимої ефективності" [Бодріяр 2000: 310].

Отож Віталій, який довший час прагнув цілковитої чи бодай тотальної соціальної справедливості, стає свідком жахливого і власне суспільно зумовленого злочину, а проте реагує на цю подію принаймні дивно. Так випадає трактувати сміх героя, коли „несподівана легкість у тілі підносила його ноги; хотілося сміятися - і він розсміявся" [Ульяненко 2013: 130].

Звісно, якщо розглядати поведінку цього персонажа через призму морально-етичних імперативів, то єдине, на що він заслуговує, - це на тавро аморального і зрадливо-ницого покидька, якого хвилює тільки його нікчемне існування. Щобільше, справа не обмежується лише радістю через те, що йому, на відміну від Цигана й інших бідолах, поталанило уникнути мученицької смерті. Віталій, по-перше, „од нечуваної радості то піднімав, то опускав обличчя, стоячи на пригорбку спуску, а місто розчепіреною п'ятірнею, мов під зором князя-владики, лежало під його ногами. I, по-друге, йому здавило мошонку, і він з солодкою млістю подумав про жінок" [Ульяненко 2013: 131].

Проте усі ці нібито дивовижі, пов'язані із проблематикою влади та сексу, цілком вписуються у філософію спокуси, принаймні за Ж. Бодріяром, який вважав, що са́ме у цьому й полягає „гра повабу - жорстока, певно, але завжди 
витончена, вишукана, відточена в нескінченно різноманітних ритуальних практиках”, через що „занадто легко тут можна забутися” і „забути про фатальну ознаку спокуси, про те, що спокуса - це доля" [Бодріяр 2000: 314].

Водночас, на думку того ж таки французького філософа, „гра спокуси” „це безособове ритуальне дійство, у якому, як і в будь-якій азартній грі, головне не виграш у вигляді розпаленої жертви і належної на цей випадок консумації, а запаморочливе ковзання у вирі гри - постійно відновлюваної, але такої, яка незмінно обертається на гру з конечністю - на гру зі смертю”, форма якої становить ,закручене «кільце кілець вічного повернення» 3 одним-єдиним, загостреним краєм”, а ,іï формула - рекурентний та рекурсивний цикл, всеосяжний і безвихідний” [Бодріяр 2000: 315].

Відтак прикметним $є$ те, що деякий час Віталія „порожнеча і відчай водять вулицями”, і він бачить: „ось вони, вчорашні повії, вчорашні внучки комісарських підстилок, батьки котрих убивали, а потім останніх одводили до Жовтневого палацу” [Ульяненко 2013: 132]. Пото́му він слухає просторікування одноокої баби Орисі про жіночі забаганки та... війну, себто про смерть. I, врешті-решт, повертається додому, де „наступні дні він відкисав у ванні, а згодом попросив у [Саньки] чисте простирадло і подався на четвертий поверх" [Ульяненко 2013: 139]. Навіть із цих побіжних згадок стає цілком очевидним, що нараторові йдеться переважно про смерть та жінок, точніше, його надзвичайно інтригує загадковість реальності, яка, як вважає коментаторка Ж. Бодріяра О. Петровська, „може тінню промайнути у спустошеному знаку”, бо „така реальність - це прихований у ній поваб” [Петровська 2000: 17].

Але, на переконання О. Петровської, „саме з цих позицій набувають доречності міркування про жіночність - перше, що відразу спадає на думку у зв’ язку із «матерією» спокуси”, оскільки за такої перспективи ,жіноче - це вже не стать як знакове утворення (подвоєння біологічного знаками соціального). Жіноче - це те, що дається взнаки взагалі з іншої сторони будь-якої очевидної і навіть субстантивованої «жіночності» - і такої, якої вдалося позбутися, і такої, що, навпаки, виявилася переможною”. Адже у запропонованому контексті жіноче необхідно трактувати, як „принцип невизначеності”, як ,торжество видимості”, як „сутність повабу”. а „,тому жіноче доцільно представити як своєрідну матрицю суб'єктивності”, бо „«жіноче», як натякає Бодрійяр, є у кожному; оскільки це аж ніяк не проблема статі, а «вічна іронія суспільності» (Гегель), то його можна вважати «архаїчною» формою суб'єктивності - навіть «архисуб'єктивності»” [Петровська 2000: 19].

Отже, йдеться про „оману власним образом, про самозакоханість, як про (інволюційне) занурення у смерть”, тобто про „входження у конечне”, -,,ось у чому, ймовірно, полягає са́ме така спокусливість «жіночого», са́ме така привабливість спокуси" [Петровська 2000: 19]. 
То чи справедливими або хоча б доречними за окресленої перспективи $€$ звинувачення Олеся Ульяненка у некрофілічних вподобаннях або нахилах? Вочевидь, ні. Бо якщо ще раз під визначеним кутом зору оглянути сюжетно-композиційний ареал роману, то тоді необхідно ствердити, що цей твір розгортається, щонайменше, на двох рівнях - суспільному та індивідуальному. Перший із них стосується глобальних трансформацій, унаслідок яких старий та звичний спосіб життя руйнується на користь нових тенденцій, що ïx визначає тривіальна, а втім, вічна жага до влади i, отже, до безсмертя. Натомість на другому рівні йдеться про не менш банальне прагнення подолати смерть - або через щасливе уникнення смертельної небезпеки, у тому числі разом із жінкою чи завдяки їй, або через сексуальну взаємодію, тобто через оволодіння жінкою.

Особливо виразно, тому що надзвичайно концентровано, окреслену конфігурацію змальовано на початку роману в історії з Люською Фішер, яка наснилася Віталію са́ме тоді, коли вже „країну колошкало” [Ульяненко 2013: 38. Герой до нестями закохався в Люську й фактично ії згвалтував, адже спочатку, „дико скрикнувши, втрачаючи навіки все: любов, повагу до цієї жінки, загнав у зад” [Ульяненко 2013: 39], а іншим разом „одним махом звалив ії на підлогу”, і вона вже „не пручалася, а віддалася легко, схлипуючи” [Ульяненко 2013: 41]. Прикметно, що в обох випадках цим сексуальним актам товаришувала смерть: у першому - „помер хтось із ваших” [Ульяненко 2013: 40], у другому - вже сам Віталій „крижанів, провалюючись у баюру, з переляканим подивом шукаючи Лідію, матір, діда, проте вгледів білі гори, піщану косу, вежі, широкі простори Океану, там, де його Золота Країна Офір, де Зелений Острів" [Ульяненко 2013: 41].

Не менш вагомо аналізована кореляція між жагою до влади, жінкою, сексом та смертю дається взнаки і в долі іншого героя - Родика. Так, цей персонаж кілька разів опинявся у межовій ситуації, як, наприклад, під час перебування в реанімаційному відділенні, борючись за життя [Ульяненко 2013: 142]. Але, попри нібито безнадійність фізичного стану, Родику поталанило подолати смерть: як цього разу просто через молодість та вчасну допомогу доктора Шмулєвича, так і наступного разу, коли, відбиваючись від нападників-педерастів, убив одного з них [Ульяненко 2013: 73]. Водночас визначальний характер життєвих колізій у долі Родика зумовлюють і гетеросексуальні мотиви. Адже коли Родик виконує роль сиділки при помираючій бабі [Ульяненко 2013: 159], то зазнає незвичайної пригоди.

\footnotetext{
... Четвертого дня прийшла вона. Та дівчина на екзотичне ім'я Ліла. і так поклалося у них за звичай, що вона влітала у брунатний морок яскравою кометою, скидаючи одяг на ходу $<\ldots>$ і вони 3 дівчиною, під харчання і прокльони баби, відда[вали]ся любощам. Хвилина, котрій позаздрять найвишуканіші некромани [Ульяненко 2013: 160].
} 
I все це на тлі того, що у телевізорі „диктор говорить [...] про неминучість третьої світової війни і що дійсність колошматить тіло" [Ульяненко 2013: 165] Родика, якому „все здавалося втраченим”, оскільки „він бачив рух смерті в натовпі”, навіть „сонце скида[ло]ся вгору, мов тінь Люцифера” [Ульяненко 2013: 171]. Тут ідеться вже навіть не про епохальний, а про інфернальний чи принаймні про трансцендентальний характер спокуси. До повищих прикладів слід додати спогади з дитинства Віталія, який разом із Родиком не раз спостерігав за тим, як його першу любов, малолітню „Лідію і Мар'яну, матір, що пустилася берега” [Ульяненко 2013: 22], „поперемінно, як кому бажалося, Роздайбіди лигали у всі дірки" [Ульяненко 2013: 27], внаслідок чого (через це підглядання) ,застукали їх [із Родиком - Ф.Ш.] на гарячому, коли вони пробували подрочити одне одному” [Ульяненко 2013: 28]. Усі ці та й інші „привиди з далекого минулого" [Ульяненко 2013: 212] підтверджують висновок, за яким, на думку О. Аронсона, „прямувати шляхом спокуси означає вибирати не зло, а відкривати гріх як ще одну можливість самого життя". Адже, як вважає цей автор, „лише піддавшись спокусі, Адам і Єва знаходять те, що ми сьогодні називаємо «свідомістю» і що є ефектом усвідомлення власної конечності, ефектом смерті. [Бо] зваба [...] - $є$ частиною життя, а не технологією, яка приховує смерть" [Аронсон 2003]. 3 ідеями О. Аронсона в цьому контексті перегукуються міркуваннями I. Камартіна, який не сумнівався щодо того, „що спокуса і здатність бути звабленим є не справою рук диявола і не крахом моралі, а безцінною властивістю людської природи, від якої, попри загальний осуд, ніхто ніколи не відмовиться" [Камартін 1998].

Таким чином, у романі Олеся Ульяненка Вогненне око йдеться про повсякчасні буттєві намагання людської істоти жити - жити, попри те, „які ми всі мізерні, страшні, божевільні до крові” [Ульяненко 2013: 176], збочені і хтиві, але водночас крихкі й тендітні через свою тілесну конечність. Натомість Вогненним оком цей твір називається тому, що „тіло, спонукане духом, тягнеться, плентається в пошуках тепла” [Ульяненко 2013: 204], проте в умовах „нудьги й порожнечі, які підігрівалися розвоєм мрії" [Ульяненко 2013: 96], либонь, „важко піднятися до неба, а ще важче впасти з неба на землю” [Ульяненко 2013: 204], бо „тільки мигдалева віянка смерті дарує повсякчас жаский подих життя" [Ульяненко 2013: 58].

Утім, таке небо можна олюднити так само, як і одискурсивити, себто охудожнити, ницу дійсність. і тому тут стане у пригоді оригінальна ідея французьких філософів Ж. Дельоза та Ф. Гваттарі, які стверджували, що схема обличчя, яку вони ще називали „абстрактною машиною фаціальності”, будується на основі сполучення білої стіни та дірок у ній. Зокрема, вони писали про те, що „обличчя будує стіну, в якій відчуває потребу те, що означає, для того, аби продертися крізь цю стіну; воно створює стіну того, що означає, створює рамку або екран. Обличчя пробиває дірку, яку потребує суб'єктивація, 
аби вдертися до неї; воно створює чорну дірку суб' єктивності у вигляді свідомості, пристрасті, камери або третього ока" [Дельоз 1987: 168], чи, зрештою, у вигляді образу Вогненного Ока.

Отже, порожнечі ницого існування, яке наратор намагається наповнити життям і смертю, символічно вторує небо з величезним оком у центрі - 3 оком, що палахкотить вогнем спокуси, тобто життєдайними теплом і світлом, шлях до яких пролягає, за Олесем Ульяненком, через бодай карнавальне перевертання жорстокості на милосердя, жахи на захват, хіті на ніжність, відрази на насолоду і навпаки. Можливо, в цьому й полягала шукана Віталієм „таємниця людського існування” [Ульяненко 2013: 102, 121], адже, як не крути, а „люди тягнуться до прекрасного, як свині до жолудів” [Ульяненко 2013: 109].

\section{Список використаної літератури}

Бодрийяр Ж., Соблазн, Москва: Ad Marginem, 2000.

Зборовська Н., Феміністичні роздуми: На карнавалі мертвих поиілунків, [в:] Електронний pecypc: http://1576.ua/books/4774 (10.09.2020).

Петровская Е., Вхождение в конечное, [в:] Бодрийяр Ж., „Соблазн”, Москва: Ad Marginem, 2000 , c. $7-21$.

Пуніна О., Самітний геній: Олесь Ульяненко: літературний портрет, Київ: Академвидав, 2016.

Харчук Р.Б., Сучасна украӥнська проза: Постмодерний період, Київ: ВЦ „Академія”, 2008.

Штейнбук Ф.М., Українська література у контексті тілесно-міметичного методу, Сімферополь: ВД „Аріал”, 2013.

Штейнбук Ф.М., Засади тілесного міметизму у текстових стратегіях постмодерністської літератури кіния XX - початку XXI століття, Київ: Педагогічна преса, 2007.

Штейнбук Ф.М., Тілесність - мімезис - аналіз (Тілесно-міметичний метод аналізу художніх творів), Київ: Знання України, 2009.

Аронсон О., Телевизионный образ, или Подражание Адаму, [в:] Электронный ресурс: http://magazines.russ.ru/nz/2003/6/art14.html (14.09.2020).

Камартин И., Совращение предусмотрено, [в:] Электронный ресурс: http://magazines.russ. ru/inostran/1998/9/kamartin.html (19.09.2020).

\section{Spysok vykorystanoi literatury [References]}

Bodryiar Zh., Soblazn [Seduction], Moskva: Ad Marginem, 2000.

Zborovska N., Feministychni rozdumy: Na karnavali mertvykh potsilunkiv [Feminist reflections. At the carnival of dead kisses], [v:] Elektronnyi resurs: http://1576.ua/books/4774 (10.09.2020). 
Petrovskaia Y., Vkhozhdeniie v konechnoie [Entering finitude], [v:] Bodryiar Zh., „Soblazn” [,Seduction”], Moskva: Ad Marginem, 2000, s. 7-21.

Punina O., Samitnyi henii:Oles Ulianenko: literaturnyi portret [The lonely genius: Oles Ulianenko: a literary portrait], Kyiv: Akademvydav, 2016.

Kharchuk R.B., Suchasna ukrainska proza: Postmodernyi period [Modern Ukrainian prose: Postmodern period], Kyiv: VTs „Akademiia”, 2008.

Shteinbuk F.M., Ukrainska literatura u konteksti tilesno-mimetychnoho metodu [Ukrainian literature in the context of corporal-mimetic method], Simferopol: VD „Arial”, 2013.

Shteinbuk F.M., Zasady tilesnoho mimetizmu u tekstovykh stratehiiakh postmodernistskoi literatury kintsia XX - pochatku XXI stolittia [Principles of corporal mimetism in text strategies of postmodernism literature at the end of XX-at the beginning of XXI century], Kyiv: Pedahohichna presa, 2007.

Shteinbuk F.M., Tilesnist - mimezys - analiz [Tilesno-mimetychnyi metod analizu khudozhnikh tvoriv) [Corporality - mimesis - analysis (Corporal-mimetic method to analyze fiction works)], Kyiv: Znannia Ukrainy, 2009.

Aronson O., Televizionnyi obraz, ili Podrazhaniie Adamu [A television image, or the Imitation of Adam], [v:] Elektronnyi resurs: http://magazines.russ.ru/nz/2003/6/art14.html (14.09.2020).

Kamartin I., Sovrascheniie predusmotreno [Seduction is supposed], [v:] Elektronnyi resurs: http://magazines.russ.ru/inostran/1998/9/kamartin.html (19.09.2020).

\section{Використане джерело}

Ульяненко О., Вогненне око, Харків: Фоліо, 2013.

\section{Vykorystane dzherelo [References]}

Ulianenko O., Vohnenne oko [Fiery eye], Kharkiv, Folio, 2013. 
